Research Article

www.ijrap.net

\title{
HEPATOPROTECTIVE ACTIVITY OF ENHYDRA FLUCTUANS LOUR. AERIAL PARTS AGAINST CCL 4 INDUCED HEPATOTOXICITY IN RATS
}

Swain Pramod Kumar ${ }^{1 *}$, Patro V. Jagannath ${ }^{2}$, Dinda Subas Chandra ${ }^{3}$, Nayak Durga Prasan ${ }^{3}$

${ }^{1}$ State Drug Testing \& Research Laboratory(ISM), Govt. Ayurvedic Hospital Campus, BJB Nagar, Bhubaneswar, India

${ }^{2}$ Roland Institute of Pharmaceutical Sciences, Khodasingi, Berhampur, Odisha, India

${ }^{3}$ School of Pharmaceutical Education \& Research, Berhampur University, Odisha, India

Received on: 09/08/12 Revised on: 18/10/12 Accepted on: 02/11/12

*Corresponding author

E-mail: tstm_22@yahoo.co.in

DOI: $10.7897 / 2277-4343.03646$

Published by Moksha Publishing House. Website www.mokshaph.com

All rights reserved.

\section{ABSTRACT}

Enhydra fluctuans Lour. an edible herbaceous vegetable plant and widely used in torpidity of liver and in nervous diseases. The different extracts (Pet-Ether extract, Chloroform extract and Ethanol extract) of Enhydra fluctuans aerial parts were studied for its hepatoprotective effect on CCl $\mathrm{C}_{4}$ induced hepatotoxic rats. The extracts were referred as PEEF, CEF and EEF respectively. In the toxicity study, all the extracts did not produce any mortality even at the highest dose $(2000 \mathrm{mg} / \mathrm{kg})$ so $200 \mathrm{mg} / \mathrm{kg}$ dose was taken as the tested dose. The extracts were found to decrease significantly $\mathrm{CCl}_{4}$-induced elevation of SGOT, SGPT, bilirubin and total cholesterol at the dose of $200 \mathrm{mg} / \mathrm{kg}$ body weight. But it increased HDL-cholesterol level and liver weight with respect to $\mathrm{CCl}_{4}$ toxic rats. Histopathological profiles of $\mathrm{CCl}_{4}$-induced hepatotoxic liver revealed extensive centrilobular necrosis extending to other necrotic areas, ballooning degeneration with steatosis. The protective effect of PEEF, CEF and EEF (200 mg/kg, p.o.) were confirmed by histopathological examination of liver section of control, $\mathrm{CCl}_{4}$-induced and extracts treated groups of rats. Though all the extracts showed remarkable effect. EEF $\left(200 \mathrm{mg} / \mathrm{kg}\right.$, p.o.) treated rats exhibited a significant improvement of hepatocellular architecture over $\mathrm{CCl}_{4}$-induced group as evident from considerable reduction in necrosis and steatosis which is comparable with the standard drug Silymarin (25mg/kg, p.o.).

KEYWORDS: Enhydra fluctuans Lour., Hepatoprotective activity, Carbon Tetrachloride, Biochemical studies, Histopathology.

\section{INTRODUCTION}

The development of Ayurveda and other traditional systems of medicines with the perspectives of safety, efficacy and quality will help not only to preserve the traditional heritage but also to rationalize the use of natural products in the health care ${ }^{1}$. Hepatic disorders remain one of the serious health problems. Numerous medicinal plants and their formulations are used for liver disorders in ethno medical practices as well as in traditional Indian medicines ${ }^{2}$. Enhydra fluctuans Lour. an edible semi-aquatic herbaceous vegetable plant with serrate leaves grows all over India. The leaves are slightly bitter; cure inflammation, skin disease and good in small pox $^{3}$. The leaves are also antibilious, used in torpidity of liver and also in nervous diseases ${ }^{4}$. It possesses nutritional value and its methanol extract has been reported to have analgesic activity ${ }^{5}$, anthelmintic and antimicrobial activity $^{6}$. The leaves of Enhydra fluctuans have been reported to have hypotensive activity ${ }^{7}$. Chemical constituents like $\beta$-carotene ${ }^{8}$, sesquiterpene lactones ${ }^{9,}{ }^{10}$, terpenes ${ }^{11}$ have been reported from this plant. Two new chlorinated melampolides ${ }^{12}$ have been isolated and reported recently. Along with this the different plant extracts were reported to contain pharmacologically active phytoconstituents like Flavonoids, Saponins, Steroids, Triterpenoids and Bitter principles ${ }^{13}$ etc. As traditional medicines it is commonly used in India for cooling, carminative, tonic, liver-tonic, leprosy, coughs and especially in hepatopathy ${ }^{14}$. In our way to investigate the local medicinal plants for their potential therapeutic uses, present study was aimed to investigate the hepatoprotective activity of petroleum ether, chloroform and ethanol extract of the aerial parts of Enhydra fluctuans.

\section{MATERIALS AND METHODS Plant Materials}

The plant was identified by the taxonomists of the Botanical Survey of India, Govt. of India, Shibpur, Howrah. After authentication fresh aerial parts of the young and matured plants were collected in bulk from the rural belt of Salipur, Odisha, India during early summer, washed, shade dried and then milled in to coarse powder by a mechanical grinder. The powder was passed through sieve number 40 and used for further studies.

\section{Extract Preparation}

The powdered plant material was extracted successively with petroleum ether $\left(60^{\circ}-80 \mathrm{C}\right)$, chloroform and ethanol using Soxhlet apparatus. The solvent was removed under reduced pressure which obtained sticky residues. Petroleum ether, chloroform and ethanol extracts were referred as PEEF, CEF and EEF respectively. The dried extracts were stored in desiccators till further study.

\section{Drugs and Chemicals}

Silymarin was purchased from Micro labs, Tamilnadu, India, and Carbon tetrachloride (SISCO Research Laboratory, Mumbai). The solvents and other reagents used were of Analytical Grade.

\section{Animals}

Studies were carried out using Wistar albino rats (150$180 \mathrm{~g}$ ) of male sex and Swiss albino mice weighing between 20 and $25 \mathrm{gm}$. On arrival the animals were placed randomly and allocated to treatment groups in poly acrylic cages $(38 \times 23 \times 10 \mathrm{~cm})$ with paddy husk as 
bedding and not more than six animals per cage. Animals were housed at a temperature of $24 \pm 2^{\circ} \mathrm{C}$ and relative humidity of $30-70 \%$. A 12:12 light: dark cycle was followed. All the animals were allowed to free access to water and fed with standard dry pellet diet (Hindustan Lever, Kolkata, India). All the experimental procedures and protocols used in this study were reviewed by the Institutional Animal Ethics Committee (1025/C/07/CPCSEA) and were in accordance with the guidelines of the CPCSEA.

\section{Acute Toxicity Studies}

Acute toxicity studies were performed according to OECD-423 guidelines ${ }^{15}$. Male Swiss albino mice selected by random sampling technique were employed in this study. The animals were fasted for $4 \mathrm{hr}$ with free access to water only. The PEEF, CEF \& EEF extracts were administered orally at a dose of $5 \mathrm{mg} / \mathrm{kg}$ initially and mortality if any was observed for 3 days. If mortality was observed in two out of three animals, then the dose administered was considered as toxic dose. However, if the mortality was observed in only one animal out of three animals then the same dose was repeated again to confirm the toxic effect. If no mortality was observed, then higher $(50,200,2000 \mathrm{mg} / \mathrm{kg})$ doses of PEEF, CEF and EEF extracts were employed for further toxicity studies.

\section{Experimental Protocols}

Healthy albino rats were divided into 6 groups each containing 6 animals. Group-I served as control and received normal saline $(2 \mathrm{ml} / \mathrm{kg}$ body weight, p.o.) once daily. Group-II received $30 \% \mathrm{CCl}_{4}$ in liquid paraffin (1 $\mathrm{ml} / \mathrm{kg}$ body weight, i.p.). Group-III, IV and $\mathrm{V}$ received PEEF, CEF and EEF (200 mg/kg, p.o) respectively and Group-VI received standard drug Silymarin $(25 \mathrm{mg} / \mathrm{kg}$, p.o) once in a day and $\mathrm{CCl}_{4}$ as mentioned above. Treatment duration was 10 days and the dose of $\mathrm{CCl}_{4}$ was administered after every $72 \mathrm{~h}^{16}$. Animals were sacrificed $24 \mathrm{~h}$ after the last injection. Blood was collected, allowed to clot and serum separated. The liver was dissected out, weighed and used for histopathological studies.

\section{Serum analysis}

After $24 \mathrm{~h}$ of the last injection, the animals of all groups were anaesthetized and sacrificed. Blood was drawn from heart and serum was separated for the assay of serum glutamate oxaloacetate transaminase (SGOT), serum glutamate pyruvate transaminase $(\mathrm{SGPT})^{17},{ }^{18}$, bilirubin (direct and total) $^{19}$ and cholesterol (total and HDL) ${ }^{20}$ using analytical kits from Span Diagnostics Ltd., Surat, India.

\section{Statistical analysis}

Statistical significance was determined by One Way Analysis of Variance (ANOVA) followed by Dunnet's ttest to compare group means. The level of significance was $\mathrm{p}<0.001$.

\section{RESULTS}

\section{Acute toxicity study}

All the doses $(5,50,200$ and $2000 \mathrm{mg} / \mathrm{kg})$ of all the three extracts of Enhydra fluctuans Lour. employed for acute oral toxicity studies were found to be non-toxic. All the extracts did not produce any mortality even at the highest dose $(2000 \mathrm{mg} / \mathrm{kg})$ employed. Therefore the $\mathrm{LD}_{50}$ value was more than $2000 \mathrm{mg} / \mathrm{kg}$ body weight. In the present study $200 \mathrm{mg} / \mathrm{kg}$ dose was taken as the tested dose.

\section{Biochemical Estimation}

The results of hepatoprotective activity of different extracts of Enhydra fluctuans on $\mathrm{CCl}_{4}$ - treated rats are shown in Table 1 . Rats subjected to $\mathrm{CCl}_{4}$ only developed significant $(\mathrm{p}<0.001)$ hepatocellular damage as evident from significant increase in serum activities of GOT, GPT and bilirubin concentration as compared to normal control group which has been used as reliable markers of hepatotoxicity. Oral administration of PEEF, CEF, EEF (200 $\mathrm{mg} / \mathrm{kg}$, p.o.) exhibited significant reduction $(\mathrm{p}<0.001)$ in $\mathrm{CCl}_{4}$-induced increase in levels of SGOT, SGPT and bilirubin (Total and Direct) concentration. Treatment with Silymarin $(25 \mathrm{mg} / \mathrm{kg}$, p.o.) also reversed the hepatotoxicity significantly $(\mathrm{p}<0.001)$. Table 1 also reveals that total serum cholesterol level of rats treated only with $\mathrm{CCl}_{4}$ increased significantly $(\mathrm{p}<0.001)$ while HDL level decreased significantly $(\mathrm{p}<0.001)$ with respect to control group. But $\mathrm{PEEF}, \mathrm{CEF}$ and $\mathrm{EEF}$ were successful in blunting this $\mathrm{CCl}_{4}$-induced increase in serum cholesterol level and decrease in HDL level which was comparable with the reference drug Silymarin. The liver weight of rats treated with $\mathrm{CCl}_{4}$ only decreased significantly $(\mathrm{p}<0.001)$ which was blunted by the extracts and Silymarin. Histopathological profiles of $\mathrm{CCl}_{4}$-induced hepatotoxic liver revealed extensive centrilobular necrosis extending to other necrotic areas, ballooning degeneration with steatosis (Photograph 2). The protective effect of $\mathrm{PEEF}, \mathrm{CEF}$ and EEF (200 mg/kg, p.o.) were confirmed by histopathological examination of liver section of control, $\mathrm{CCl}_{4}$-induced and extracts treated groups of rats. Though all the extracts showed remarkable effect, EEF $(200 \mathrm{mg} / \mathrm{kg}$, p.o.) treated rats exhibited a significant improvement of hepatocellular architecture over $\mathrm{CCl}_{4}$ induced group as evident from considerable reduction in necrosis and steatosis (Photograph 5). Liver section of rats treated with Silymarin $(25 \mathrm{mg} / \mathrm{kg}$, p.o.) showed significant signs of amelioration of $\mathrm{CCl}_{4}$-induced liver injury which was evident from normal liver architecture and absence of necrosis and steatosis (Photograph 6). The study showed that EEF and Silymarin showed significant protective effect against $\mathrm{CCl}_{4}$-induced liver injury which was evident from their histopathological examination.

\section{DISCUSSION}

Out of all the hepatotoxin, $\mathrm{CCl}_{4}$ is the most commonly used hepatotoxin in the experimental study of liver disease $^{21}$. It is well documented that carbon tetrachloride is biotransformed under the action of cytochrome $\mathrm{P}_{450}$ in the microsomal compartment of liver to trichloromethyl radical which readily reacts with molecular oxygen to form trichloromethylperoxy radical $^{22}$. Both the radicals can bind covalently to the macromolecules and induce peroxidative degradation of the membrane lipids of endoplasmic reticulum rich in polyunsaturated fatty acids. This leads to the pathological changes such as elevated levels of serum marker enzymes such as SGOT, SGPT and bilirubin ${ }^{23}$. 
Swain Pramod Kumar et al / IJRAP 3(6), Nov - Dec 2012

Table 1: Effect of PEEF, CEF, EEF (200mg/kg, p.o.) on SGOT, SGPT, bilirubin, cholesterol and liver weight on $\mathrm{CCl}_{4}$ induced hepatotoxicity in rats

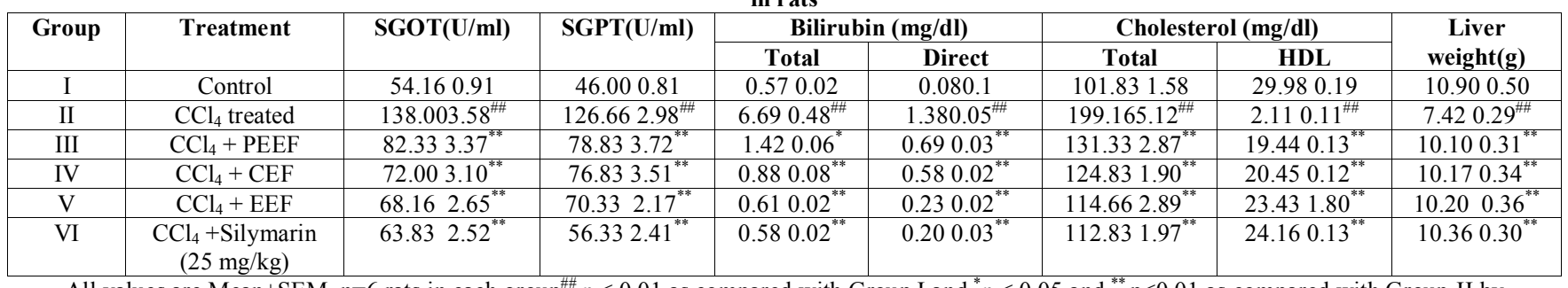

All values are Mean \pm SEM, $\mathrm{n}=6$ rats in each group ${ }^{\# \#} p<0.01$ as compared with Group I and ${ }^{*} p<0.05$ and $^{* *} \mathrm{p}<0.01$ as compared with Group-II by Dunnetts multiple comparison

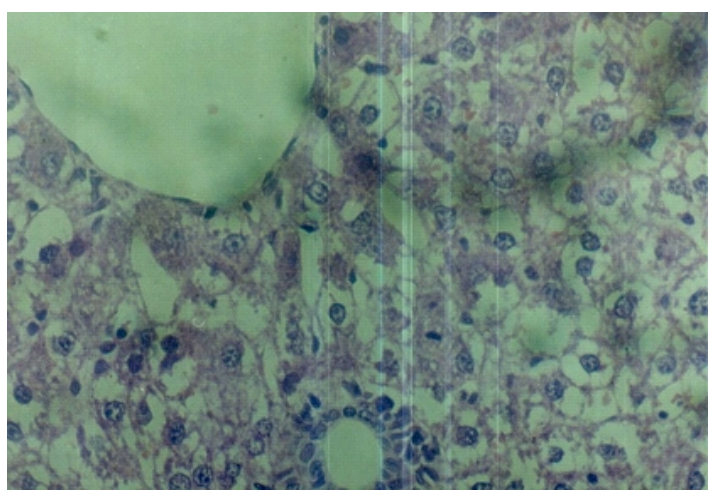

Photograph 1: Section of liver tissue of normal rat showing normal liver architecture with central vein and portal triads $(\mathrm{H} \& \mathrm{E}, 400 \mathrm{x})$



Photograph 2: Section of liver tissue of rat induced with $\mathrm{CCl}_{4}$ showing extensive centrilobular necrosis, extending to other necrotic areas, ballooning degeneration along with fatty degeneration or steatosis $(H \& E, 200 x)$

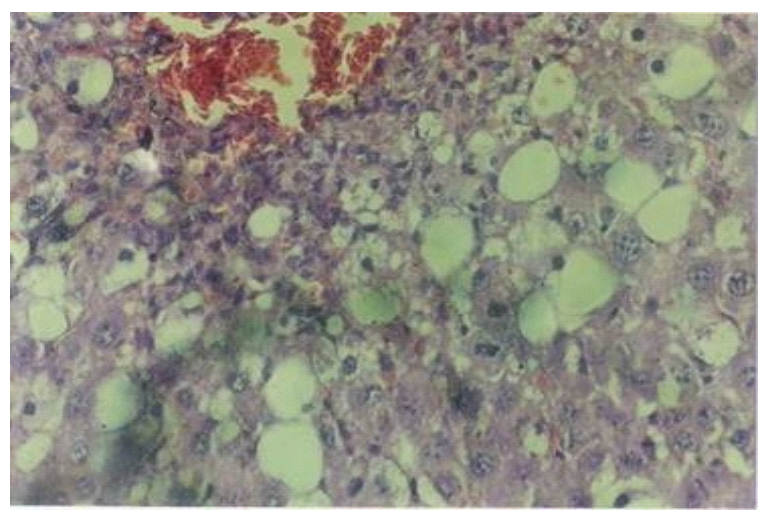

Photograph 3: Section of liver tissue of rat treated with Pet-Ether (PEEF) extract $(200 \mathrm{mg} / \mathrm{kg}$, p.o.) Showing abnormal liver architecture with steatosis and huge sinusoidal congestion $(H \& E$, 400x)

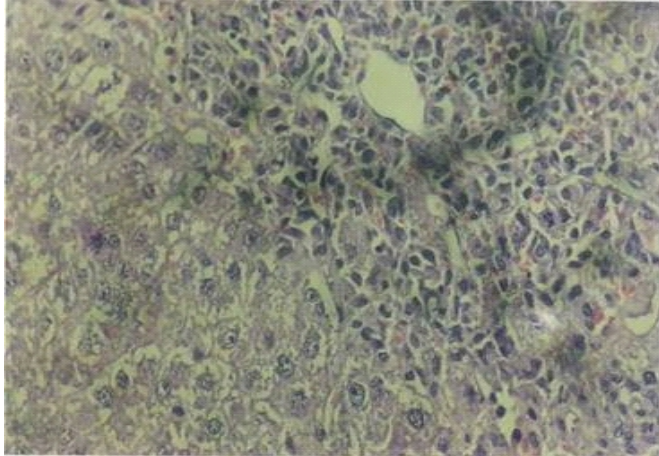

Photograph 4: Section of liver tissue of rat treated with Chloroform (CEF) $(200 \mathrm{mg} / \mathrm{kg}$, p.o.) showing abnormal liver architecture with no necrosis, but less steatosis and mild sinusoidal congestion $(H \& E 400 x)$

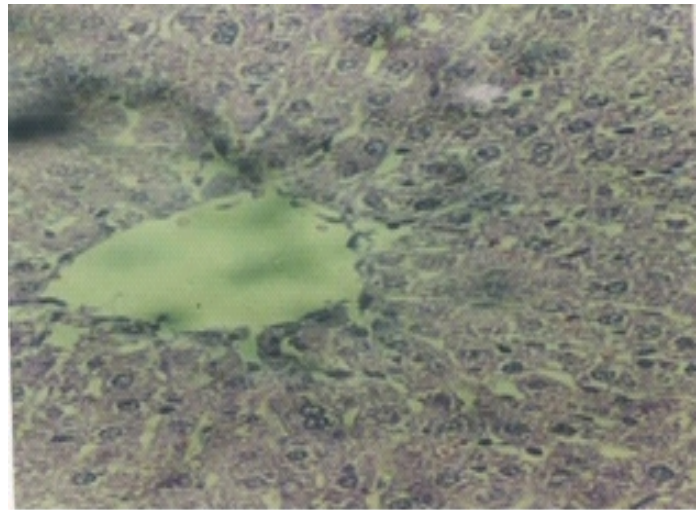

Photograph 5: Section of liver tissue of Ethanol extract (EEF) treated $(200 \mathrm{mg} / \mathrm{kg}$, p.o.) rat showing almost no necrosis, diffuse steatosis and mild increase in inflammatory cells in portal tract $(\mathrm{H}$ $\& \mathbf{E}, 400 x)$

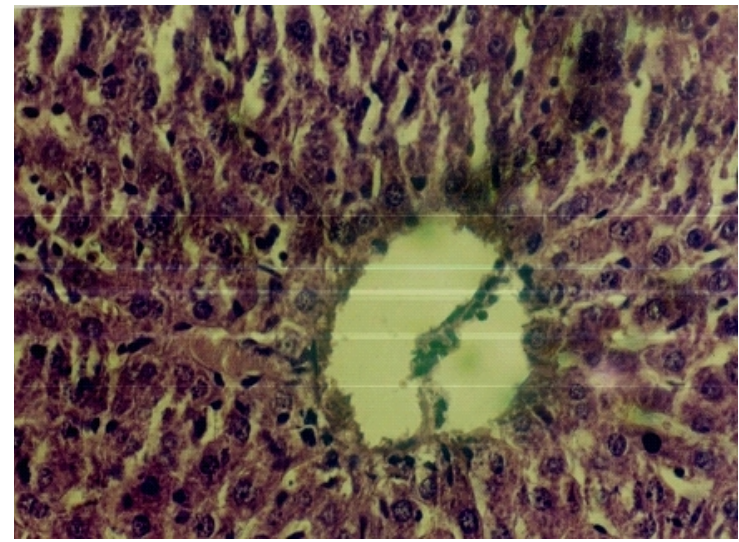

Photograph 6: Section of liver tissue of rat treated with Silymarin $(25 \mathrm{mg} / \mathrm{kg}$, p.o.) showing almost normal liver architecture with no necrosis, no steatosis and mild sinusoidal congestion (H\&E,400x) 
The assessment of liver function can be made by estimating the activities of these serum enzymes. During liver damage there may be an increase in these enzyme levels in serum with the extent of liver damage. The elevated or altered levels of these enzymes in the $\mathrm{CCl}_{4}-$ treated experimental animals in the present investigation corresponded to the extensive liver damage induced by the hepatotoxin.

The hepatoprotective activity of PEEF, CEF and EEF were monitored by estimating serum transaminases and bilirubin which give a good idea about the functional state of the liver ${ }^{24}$. Necrosis or membrane damage releases the enzymes into circulation and therefore it can be measured in serum. The increase in the level of serum bilirubin reflected the depth of jaundice and increase of serum transaminases was a clear indication of cellular leakage and loss of functional integrity of cell membrane ${ }^{25}$. Our results demonstrate that PEEF, CEF and EEF caused significant inhibition of SGOT, SGPT and bilirubin levels when compared to $\mathrm{CCl}_{4}$-induced hepatotoxic rats. Effective control of levels of serum transaminases and bilirubin level points towards an early improvement in secretory mechanism of hepatic cells.

Results of the present studies, suggest that as compare to PEEF and CEF the EEF extract has an ability to protect the liver from $\mathrm{CCl}_{4}$-induced liver damage. The protective activity of the extract may be attributed to the membrane stabilizing agents present in the plant which may avert enzyme leakages in tissues in response to $\mathrm{CCl}_{4}$ poisoning ${ }^{26}$. Certainly further studies need to be carried out with other hepatotoxic compounds to prove the hepatoprotective efficacy along this, studies are needed to isolate and characterize the compounds responsible for the above effect.

\section{ACKNOWLEDGEMENT}

The authors are thankful to the Head, State Drug Testing \& Research Laboratory(ISM), Govt. of Odisha, The Director, School of Pharmaceutical Education \& Research, Berhampur University, Berhampur, Odisha for the technical support to carryout the research work and the taxonomists of Botanical Survey of India, Shibpur, Howrah for proper identification of the plant.

\section{REFERENCES}

1. Sahoo R, Swain PK, Acharya R. Standardization of a polyherbal Ayurvedic formulation Sulaharan Yoga. International Journal of Research in Ayurveda \& Pharmacy 2011; 2(3):704-707.

2. Babu HT, Shylesh BS, Padikkala J. Antioxidant and hepatoprotective effect of Acanthus ilicifolius. Fitoterapia 2001 72:272-277. http://dx.doi.org/10.1016/S0367-326X(00)00300-2

3. Kirtikar KR, Basu BD. Indian Medicinal Plants.Derhadun:1999p. 1360.

4. Ghani A. Medicinal plants of Bangladesh.Dhaka:1998. p. 170.
5. Rahman MT, Begum N, Alimuzzaman M, Khan MOF. Analgesic activity of Enhydra fluctuans. Fitoterapia 2002; 73:77-79. http://dx.doi.org/10.1016/S0367-326X(02)00212-5

6. Ghosh T, Maity TK, Swain PK, Bose A. Anthelmintic and antimicrobial activity of Enhydra fluctuans Lour. aerial parts. Pharmcognosy Magazine 2007; 11(suppl):204-208.

7. Joshi BS, Kamat VN. Structure of enhydrin, a germacronolide from Enhydra fluctuans. Ind. J. Chem. 1972; 10:771-776.

8. Dewanji A, Matai S, Si SL, Barik S, Nag A. Chemical composition of two semi aquatic plant for food use. Plants Foods Hum. Nutr. 1993; 44:11-15. $\quad$ http://dx.doi.org/10.1007/BF01088478 PMid:8332583

9. Krishnaswami NR, Seshadri TR, Sharma B. Chemical components of Enhydra fluctuans. R. Curr. Sci. 1968; 37: 94-98.

10. Ali E, Ghosh PP, Dastidar SC, Pakrashi AM. Sesquiterpene lactones of Enhydra fluctuans. Tetrahedron 1972; 28:2285-2292. http://dx.doi.org/10.1016/S0040-4020(01)93572-0

11. Krishnaswamy NR, Prasanna S. Cholesterol from Enhydra fluctuans. Phytochemistry 1975; 14:1663-1668. http://dx.doi.org/ $\underline{\text { 10.1016/0031-9422(75)85383-0 }}$

12. Krishnaswamy NR, Ramji N. Phytochemistry 1995; 38:433. http://dx.doi.org/10.1016/0031-9422(94)00705-X

13. Ghosh T, Maity TK, Swain PK, Bose A. Anthelmintic and antimicrobial activity of Enhydra fluctuans Lour. aerial parts. Pharmcognosy Magazine 2007; 11(suppl):206.

14. Swain BK, Dash SK. Visual Guide to Wild Medicinal Plants of Orissa. 1st ed. Govt. of Orissa: Jyotigraphics; 2007. p. 135.

15. Ecobichon DJ. The basis of toxicology testing. New York: CRC Press; 1997. p. 43-86.

16. Manoj B, Aqueed K. Protective effect of Lawsonia alba Lam., against CC14-induced hepatic damage in albino rats. Ind. J. Expt. Biol.2003; 41: 85-87.

17. Rietman S, Frankel S. A colorimetric determination of serum glutamic oxaloacetic and glutamic pyruvic transaminases. Am. J. Clin. Pathol. 1957; 28: 56-63.

18. King J. The hydrolases-acid and alkaline phospatase. In, Practical Clinical Enzymology, ed. by D. Van, Nostrand company Ltd., London; 1965. P. 191-208.

19. Malloy HT, Evelyn KA. The determination of bilirubin with the photometric colorimeter. J. Biol. Chem. 1937; 481-490.

20. Warnick GR, Nguyen Y, Albers AA. Comparison of improved precipitation methods for quantification of high density lipoprotein cholesterol. Clin. Chem. 1985; 31: 217-221. PMid:2578337

21. Johnson DE, Kroening C. Mechanism of early Carbon tetrachloride toxicity in cultured rat hepatocytes. Pharmacol Toxicol 1998; 83: 231-9. http://dx.doi.org/10.1111/j.1600-0773.1998.tb01475.x

22. Raucy JL, Kraner JC, Lasker J. Bioactivation of halogenated hydrocarbons by cytochrome P 450 E1. Crit. Rev. Toxicol. 1993; 23: $\quad 1-20 . \quad$ http://dx.doi.org/10.3109/10408449309104072 PMid:8471158

23. Zimmerman HJ, Seeff LB. Enzymes in hepatic disease, Lea and Febiger, Philadelphia, 1970; 24-26.

24. Rao KS, Mishra SH. Anti-inflammatory and hepatoprotective activities of Sida rhombifolia Linn. Indian J Pharmacol. 1997; 29: 110-116.

25. Saraswat B, Visen PK, Patnaik GK, Dhawan BN. Anticholeststic effect of Picroliv, active hepatoprotective principle of Picrorhiza kurrooa against CCl4 induced cholestasis. Indian J. Expt. Biol. 1993; 31: 316-318. PMid:8359830

26. Mandal PK, Bishayee A, Chatterjee M. Studies of hepatic protein synthesis in response to Mikania cordate root extract in CCl4 induced hepatotoxicity in mice. Ital J Biochem 1992; 431: 345-50.

\section{Cite this article as:}

Swain Pramod Kumar, Patro V. Jagannath, Dinda Subas Chandra, Nayak Durga Prasan. Hepatoprotective activity of Enhydra fluctuans Lour. aerial parts against CCl4 induced hepatotoxicity in rats. Int. J. Res. Ayur. Pharm. 2012; 3(6):893-896 